\title{
SENSE OF PLACE AND SOCIAL ANXIETY RELATIONS OF NEW COMERS OF RADEN INTAN STATE ISLAMIC UNIVERSITY, LAMPUNG
}

\author{
Agus Jatmiko \\ Tarbiyah and Teacher Training Faculty UIN Raden Intan Lampung \\ agusjatmiko@radenintan.ac.id
}

\begin{abstract}
Migration is a form of migration that can be seen in several regions in Indonesia. Wandering not only occurs in finding work but also in students who will continue their education in college. Migrant students will experience situations that are different from life in their place of origin, for example differences in culture, language and communication. As social beings we cannot be separated from interaction, where in this interaction a special feeling will be formed that is received by humans produced from a place with various elements in it, including those who live in it, this special feeling is called the sense of place. In interacting not all individuals feel safe and comfortable, but there are also those who have feelings of anxiety, fear, or worry about the surrounding environment, anxiety or concern related to social situations is called social anxiety. This study uses quantitative research methods with the subject of 90 students from Tarbiyah and Teaching Faculty of Lampung State Islamic University as chosen by using the sample technique, namely purposive sampling. Data collection uses a questionnaire about the variable sense of place and social anxiety variables. Hypothesis testing in this study uses Product Moment correlation analysis. The conclusion of the study is that there is a relationship between the sense of place and social anxiety on students from the Tarbiyah Faculty of Education and Teacher Training at the State Islamic University Raden Intan Lampung.
\end{abstract}

Keywords : New Comer, Sense of Place, Social Anxiety 


\section{INTRODUCTION}

Migrants are common things often found in any place or area, and generally they do not stay long and do not stay forever in the area. Similarly, migrating is a form of migration that can be seen in several regions in Indonesia. The phenomenon of 'wander' is defined by Leake in Kartono as ' leaving home to seek wealth, knowledge and fame (R. Leake, 2008). One of the faculties at the Raden Intan Lampung State Islamic University (UIN) is the Tarbiyah Faculty and Teaching. Based on the pre-survey data obtained from the official website of the Tarbiyah and Teaching Faculty UIN Raden Intan Lampung, it can be seen that the students who enroll every year always experience an increase. Students who register are not only students from Bandar Lampung, but immigrant students, then what is meant by immigrant students in this study are students who come from outside the Bandarlampung area and have never lived in Bandarlampung before.

In this new place, newcomer students will experience a situation different from life in their place of origin, for example differences in culture, language and communication, from the differences in circumstances, the immigrant students must be able to adapt to their new environment. In addition, the newcomer student cannot be separated from the interaction, where in this interaction will be formed a special feeling that is received by humans produced from a place with various elements in it, including the people who live in it, this special feeling is called sense of place (Arief, 2015). According to Rostamzadeh, Anantharaman and Tong ( 2012 ) the sense of place is a topic of environmental psychology that is defined as the emotional relationship between place and human.

Sense of place is not only imbued from physical settings, but from human interpretation of the setting (Jorgensenet al., 200 1). Hashemnezhad in Nurhayati ( 2015 ) said that the sense of place is a comprehensive concept in which humans can feel a place, perceive themselves and have an attachment to a place that matters to them. Sense of place begins with the sensation they receive from an environment, the sensation can be in the form of atmosphere and the impression generated is then perceived by the individual, the perception that emerges can make a subjective meaning to the place. D ari interaction will form a special juice or purport to somewhere. The meaning can be in the form of good or bad meaning ( Arief , 2015). Bad meaning for newcomers can be a stressor. In line with what was said by Iskandar (2012), the environment around humans provides stimulation that can be interpreted as a stressor or stimulus that can cause pressure on someone. 
Stimulus from the environment will be judged by individuals, where in this assessment will emerge a reaction and as a result if an individual can overcome the stimulus coming from the environment a condition will be created, the condition can be adaptation (tolerating the environment) or adjustment(individuals change the environment to suit it ) Conversely, if individuals fail to overcome the stimulus that comes there will be stress, anxiety, illness and so forth.

The existence of cultural differences and not yet know each other will cause a person psychologically to experience anxiety ( Setiowati, Wahyuningtyas and Citra, 2013). Anxiety is an unpleasant emotional condition, characterized by subjective feelings such as tension, fear and concern (Muarifah, 2005). As individual social beings can not be separated from interaction, where in interaction not all individuals feel safe and comfortable, but there are also those who have feelings of anxiety, fear, or worry about the surrounding environment, anxiety or concern related to social situations is called social anxiety ( Prawoto, 2010).

Social anxiety is a form of anxiety and fear directed at the social environment. Individuals worry that they will get negative ratings from others. Individuals are also worried about being unable to get approval from other people and afraid of committing shameful behavior in public. Social anxiety is a permanent and irrational fear that is generally related to the existence of others. (Davision, Neale, \& Kring, 2012 ). Individuals with social anxiety worry about being constantly monitored and seen negatively by others and display a great deal of anxiety related to symptoms and behavior before, during, and after social events ( Villiers , 2008).

Someone who experiences social anxiety is basically not confident to interact with others, they feel that they will do something to embarrass themselves, or others will judge them too hard and critical ( Prawoto , 2010).

People with social anxiety judge themselves to be worse than others and reduce their abilities and performance so that they are really worse ( Swasti and Martani , 2013). Social anxiety in cases that occur to some students can prevent them from completing their educational goals and if this continues to be feared it will prevent them from advancing in their careers (Muarifah, 2005). The relationship between humans and the environment can be seen from the theory proposed by Lewin. where it is said that behavior is a function of humans and the environment (Villiers, 2008). Individuals differ in how they manage their sustainability with the environment, day by day, hourly hours and there is reason to believe that these differences have many relationships with the overall quality of their 
adjustments, including their health or moral illness, and adaptive functions ( Altma and Wohlwill, 1977)

Sense of place has a role in social anxiety, the negative impact that can be caused from social anxiety one of them is to reduce individual academic performance, while students are required to be able to achieve a certain achievement index (IP), if social anxiety experienced by immigrant students causes academic performance to fall, it is not impossible that this situation can make immigrant students unable to survive. Therefore, this study examines the relationship between the sense of place and social anxiety on immigrant students in the Tarbiyah and Teaching Faculty of the Raden Intan Lampung State Islamic University.

\section{DISCUSSION}

1. Theory Description

That the sense of place is the meaning given by the individual to a place with various elements in it including the physical setting of the place itself, the experience experienced by the individual towards the place and the interaction that is intertwined with other individuals. Sense of place begins with the sensation that individuals receive from an environment, from that sensation can form a perception where perceptions that arise can form a subjective meaning to the place.

Social Anxiet $y$ or another term is social anxiety that is the experience of fear, anxiety or worry about social situations and fear of being evaluated by others. This can occur due to negative experience, hostility or special experience with peers which may further hamper the social interaction needed forsocioemosional development ( Juntilla et al., 2011)

Social anxiety is a phenomenon characterized by fear and distress. Social anxiety is characterized by seeing social interaction as competitive, excessive awareness of social threat signs, and avoiding interactions that can lead to social rejection. On the extreme scale of social immunity is related to mental health conditions, such as problems with substance abuse, depression, suicidal desires, and suicide attempts ( Rahmawati, Yusainy, Nurwanti, and Selfie, 2014).

Social anxiety as a permanent and irrational fear that is generally related to the presence of others (Davision et al ., 2012). Individuals with social anxiety usually try to avoid situations where they might be assessed and show signs of anxiety or embarrassing behavior. The essence of social anxiety is the fear of shame and humiliation in social situations ( Kreifeltset al ., 2014). 
Social anxiety increases to disturbance if; first, the level of anxiety experienced is increasingly irrational and interferes with the effectiveness of daily activities, second, justification of excessive anxiety, for example individuals feel high levels of anxiety without trigger stimuli, and third, the consequences of anxiety bring a comprehensive negative impact on individual life ( Swasti and Martani , 2013).

2. Research result

a. Description of research subjects based on age

Table 1. Description of Age Subjects Age

\begin{tabular}{cccr}
\hline No. & Age & amount & Percentage \\
\hline 1 & 17 & 3 & $8.9 \%$ \\
\hline 2 & 19 & 56 & $55.92 \%$ \\
\hline 3 & 18 & 14 & $31.11 \%$ \\
\hline 4 & 20 & 13 & $8.51 \%$ \\
\hline 5 & 21 & 4 & $3.33 \%$ \\
\hline & amount & 90 & $100 \%$ \\
\hline
\end{tabular}

From Table 1. above can be seen the subjects in this study have an age range ranging from 17-21 years. The 19-year-old subject had the highest percentage in this study, then subjects with the age of 18 had the second highest percentage. Furthermore, subjects with age of 17 years as many as 3 people, subjects with age 20 as many as 13 , and age 21 years as many as 4 people.

b. Subject description based on gender

Table 2. Description of the sex of the subject

\begin{tabular}{clcr}
\hline No. & Gender & $\begin{array}{c}\text { Number of } \\
\text { Subjects }\end{array}$ & Percentage \\
\hline 1 & Man & 32 & $35.56 \%$ \\
\hline 2 & Woman & 58 & $64.44 \%$ \\
\hline & amount & 90 & $100 \%$ \\
\hline
\end{tabular}

c. Subject description based on department / study program

Table 3. Description of Subject Study Programs / Programs

\begin{tabular}{rlrr}
\hline No. & \multicolumn{1}{c}{ Majors courses } & $\begin{array}{c}\text { Number of } \\
\text { Subjects }\end{array}$ & Percentage \\
\hline 1 & Islamic education & 22 & $24.44 \%$ \\
\hline 2 & Arabic Language Education & 6 & $6.67 \%$ \\
\hline
\end{tabular}




\begin{tabular}{rlrr}
\hline 3 & Management of Islamic Education & 10 & $11.11 \%$ \\
\hline 4 & English language education & 4 & $4.44 \%$ \\
\hline 5 & Mathematics education & 12 & $13.33 \%$ \\
\hline 6 & Biology Education & 14 & $15.56 \%$ \\
\hline 7 & Physical education & 8 & $8.89 \%$ \\
\hline 8 & $\begin{array}{l}\text { Raudhatul Atfal Teacher } \\
\text { Education }\end{array}$ & 5 & $5.56 \%$ \\
\hline 9 & $\begin{array}{l}\text { Madrasah Ibtidaiyah Teacher } \\
\text { Education }\end{array}$ & 4 & $4.44 \%$ \\
\hline 10 & Islamic Guidance and Counseling & 5 & $5.56 \%$ \\
\hline \multicolumn{2}{c}{ amount } & 90 & $100 \%$ \\
\hline
\end{tabular}

Subjects in this study were students of the Tarbiyah and Teaching Faculty entrants consisting of 10 majors or study programs. Based on Table 3. above can be seen the number or percentage of research subjects based on majors / study programs as follows: Subjects from the department / study program of Islamic Religious Education as many as 21 people (24.44\%), Arabic Language Education as many as 6 people (6.67 \%), Islamic Education Management as many as 10 people (11.11\%), English Language Education as many as 4 people (4,44\%), Mathematics Education as many as 12 people (13.33\%), Biology Education as many as 14 people (15.56 \%), Physics Education as many as 8 people $(8.89 \%)$, Raudhatul Atfal Teacher Education as many as 5 people $(5.56 \%)$, Madrasah Ibtidaiyah Teacher Education as many as 4 people (4.44\%), and Guidance and Counseling majors or study programsIslam as many as 5 people $(5.56 \%)$,

c. Description of subject based on original domicile

Table 4. Description of domosili origin of the subject

No. Domosili Origin of Subject Number of Percentage

Subjects

\begin{tabular}{rlrr}
\hline 1 & North Lampung Regency & 18 & $20 \%$ \\
\hline 2 & South Lampung Regency & 14 & $15.56 \%$ \\
\hline 3 & West Lampung Regency & 20 & $22.22 \%$ \\
\hline 4 & East Lampung Regency & 4 & $4.44 \%$ \\
\hline 5 & Central Lampung Regency & 3 & $3.33 \%$ \\
\hline 6 & Tanggamus Regency & 18 & $20 \%$ \\
\hline
\end{tabular}




\begin{tabular}{ccrr}
\hline 7 & Tulang Bawang Regency & 4 & $4.44 \%$ \\
\hline 8 & Another city & 9 & $10.00 \%$ \\
\hline \multicolumn{2}{c}{ amount } & 90 & $100 \%$ \\
\hline
\end{tabular}

Description of the subject was also divided based on the domicile of the origin of the subject, the subject came from the North Lampung Regency City of the Earth and its surroundings amounted to 18 people $(20.00 \%)$, the subject came from South Lampung Regency as many as 14 people(15.56\%), the subject came from West Lampung Regency as many as 20 people (22.22\%). Subjects from Jawatengah were 7 people $(2.59 \%)$, subjects from East Lampung Regency were 4 people (4.44\%), subjects from Central Lampung District were 3 people (3.33\%), subjects from Tanggamus Regencyas many as 18 people $(20.00 \%)$, the subjects came from Tulang Bawang Regency as many as 4 people $(4.44 \%)$, and the subjects came from other cities outside the seven cities mentioned previously as many as 9 people $(10.00 \%)$.

\section{Hypothesis testing}

Hypothesis testing in this study uses non-parametric analysis methods because the data in this study are not normally distributed. Test the hypothesis in this study using the Spearman Rank Correlation method. Spearman rank correlation test is used to test the associative hypothesis between variables if the data used has the least ordinal scale data ( Suliyanto, 2014).

Table 5. Correlation Test

\begin{tabular}{cccc}
\hline Variable & $\begin{array}{c}\text { Significance } \\
\text { Value }\end{array}$ & $\begin{array}{c}\text { Level of } \\
\text { Significance }\end{array}$ & $\begin{array}{c}\text { Correlation } \\
\text { coefficient }\end{array}$ \\
\hline $\begin{array}{c}\text { Sense of place } \\
\text { against }\end{array}$ & 0.00 & 0.05 & $-0,272$ \\
Social anxiety & & & \\
\hline
\end{tabular}

Based on Table 5. above the results of spearman rank correlation analysis shows that the significance value is 0.00 because the significance value is smaller than 0.05, it can be concluded that $H_{o}$ is rejected and $H_{a}$ $i s$ accepted. This means that there is a significant relationship between the sense of place and social anxiety on new students of the Tarbiyah and Teaching Faculties of the State Islamic University Raden Intan 
Lampung. Negative correlation coefficient shows a negative relationship between variable $(\mathrm{X})$ and variable $(\mathrm{Y})$, meaning that if the sense of place increases, social anxiety decreases, and vice versa, if the sense of place decreases, social anxiety increases.

\section{Theory Description}

That the sense of place is the meaning given by the individual to a place with various elements in it including the physical setting of the place itself, the experience experienced by the individual towards the place and the interaction that is intertwined with other individuals. Sense of place begins with the sensation that individuals receive from an environment, from that sensation can form a perception where perceptions that arise can form a subjective meaning to the place.

Social Anxiety or another term is social anxiety which is the experience of fear, anxiety or worry about social situations and fear of being evaluated by others. This can occur due to negative experience, hostility or special experience with peers which may further hamper the social interaction needed for socio-emotional development (Juntilla et al., 2011)

Social anxiety is a phenomenon characterized by fear and distress. Social anxiety is characterized by seeing social interaction as competitive, excessive awareness of social threat signs, and avoiding interactions that can lead to social rejection. On the extreme scale of social immunity is related to mental health conditions, such as problems with substance abuse, depression, suicidal desires, and suicide attempts ( Rahmawati, Yusainy, Nurwanti, and Selfie, 2014).

Social anxiety as a permanent and irrational fear that is generally related to the presence of others (Davision et al., 2012). Individuals with social anxiety usually try to avoid situations where they might be assessed and show signs of anxiety or embarrassing behavior. The essence of social anxiety is the fear of shame and humiliation in social situations ( Kreifeltset al ., 2014).

Social anxiety increases to disturbance if; first, the level of anxiety experienced is increasingly irrational and interferes with the effectiveness of daily activities, second, justification of excessive anxiety, for example individuals feel high levels of anxiety without trigger stimuli, and third, the consequences of anxiety bring a 
comprehensive negative impact on individual life ( Swasti and Martani , 2013).

\section{Research Results}

a. Description of research subjects based on age Table 1. Description of Age Subjects Age

\begin{tabular}{cccr}
\hline No. & Age & amount & Percentage \\
\hline 1 & 17 & 3 & $8.9 \%$ \\
\hline 2 & 19 & 56 & $55.92 \%$ \\
\hline 3 & 18 & 14 & $31.11 \%$ \\
\hline 4 & 20 & 13 & $8.51 \%$ \\
\hline 5 & 21 & 4 & $3.33 \%$ \\
\hline & amount & 90 & $100 \%$ \\
\hline
\end{tabular}

From Table 1. above can be seen the subjects in this study have an age range ranging from 17-21 years. The 19-year-old subject had the highest percentage in this study, then subjects with the age of 18 had the second highest percentage. Furthermore, subjects with age of 17 years as many as 3 people, subjects with age 20 as many as 13 , and age 21 years as many as 4 people.

b. Subject description based on gender

Table 2. Description of the sex of the subject

\begin{tabular}{clcr}
\hline No. & Gender & $\begin{array}{c}\text { Number of } \\
\text { Subjects }\end{array}$ & Percentage \\
\hline 1 & Man & 32 & $35.56 \%$ \\
\hline 2 & Woman & 58 & $64.44 \%$ \\
\hline & amount & 90 & $100 \%$ \\
\hline
\end{tabular}

c. Subject description based on department / study program

Table 3. Description of Subject Study Programs / Programs

\begin{tabular}{rlrr}
\hline No. & \multicolumn{1}{c}{ Majors courses } & $\begin{array}{c}\text { Number of } \\
\text { Subjects }\end{array}$ & Percentage \\
\hline 1 & Islamic education & 22 & $24.44 \%$ \\
\hline 2 & Arabic Language Education & 6 & $6.67 \%$ \\
\hline 3 & Management of Islamic Education & 10 & $11.11 \%$ \\
\hline 4 & English language education & 4 & $4.44 \%$ \\
\hline 5 & Mathematics education & 12 & $13.33 \%$ \\
\hline 6 & Biology Education & 14 & $15.56 \%$ \\
\hline & & & \\
\hline
\end{tabular}




\begin{tabular}{clrr}
\hline 7 & Physical education & 8 & $8.89 \%$ \\
\hline 8 & $\begin{array}{l}\text { Raudhatul Atfal Teacher } \\
\text { Education }\end{array}$ & 5 & $5.56 \%$ \\
\hline 9 & $\begin{array}{l}\text { Madrasah Ibtidaiyah Teacher } \\
\text { Education }\end{array}$ & 4 & $4.44 \%$ \\
\hline 10 & Islamic Guidance and Counseling & 5 & $5.56 \%$ \\
\hline \multicolumn{2}{c}{ Amount } & 90 & $100 \%$ \\
\hline
\end{tabular}

Subjects in this study were students of the Tarbiyah and Teaching Faculty entrants consisting of 10 majors or study programs. Based on Table 3. above can be seen the number or percentage of research subjects based on majors / study programs as follows: Subjects from the department / study programof Islamic Religious Education as many as 21 people $(24.44 \%)$, Arabic Language Education as many as 6 people (6.67 \%), Islamic Education Management as many as 10 people (11.11\%), English Language Education as many as 4 people (4, $44 \%$ ), Mathematics Education as many as 12 people (13.33\%), Biology Education as many as 14 people (15.56 \%), Physics Education as many as 8 people (8.89\%), Raudhatul Atfal Teacher Education as many as 5 people (5.56\%), Madrasah Ibtidaiyah Teacher Education as many as 4 people (4.44\%), and Guidance and Counseling majors or study programs Islam as many as 5 people $(5.56 \%)$,

d. Description of subject based on original domicile

Table 4. Description of domosili origin of the subject

No. Domosili Origin of Subject Number of Percentage Subjects

\begin{tabular}{rlrr}
\hline 1 & North Lampung Regency & 18 & $20 \%$ \\
\hline 2 & South Lampung Regency & 14 & $15.56 \%$ \\
\hline 3 & West Lampung Regency & 20 & $22.22 \%$ \\
\hline 4 & East Lampung Regency & 4 & $4.44 \%$ \\
\hline 5 & Central Lampung Regency & 3 & $3.33 \%$ \\
\hline 6 & Tanggamus Regency & 18 & $20 \%$ \\
\hline 7 & Tulang Bawang Regency & 4 & $4.44 \%$ \\
\hline 8 & Another city & 9 & $10.00 \%$ \\
\hline & Amount & 90 & $100 \%$ \\
\hline
\end{tabular}

Description of the subject was also divided based on the domicile of the origin of the subject, the subject came from the North Lampung 
Regency City of the Earth and its surroundings amounted to 18 people (20.00\%), the subject came from South Lampung Regency as many as 14 people (15.56\%), the subject came from West Lampung Regency as many as 20 people (22.22\%). Subjects from Jawatengah were 7 people $(2.59 \%)$, subjects from East Lampung Regency were 4 people (4.44\%), subjects from Central Lampung District were 3 people (3.33\%), subjects from Tanggamus Regency as many as 18 people $(20.00 \%)$, the subject came from Tulang Bawang Regency as many as 4 people $(4.44 \%)$, and the subjects came from other cities outside the seven cities mentioned previously as many as 9 people (10, $00 \%)$.

\section{Hypothesis Testing}

Hypothesis testing in this study uses non-parametric analysis methods because the data in this study are not normally distributed. Test the hypothesis in this study using the Spearman Rank Correlation method. Spearman rank correlation test is used to test the associative hypothesis between variables if the data used has the least ordinal scale data ( Suliyanto , 2014).

Table 5. Correlation Test

\begin{tabular}{cccc}
\hline Variable & $\begin{array}{c}\text { Significance } \\
\text { Value }\end{array}$ & $\begin{array}{c}\text { Level of } \\
\text { Significance }\end{array}$ & $\begin{array}{c}\text { Correlation } \\
\text { coefficient }\end{array}$ \\
\hline $\begin{array}{c}\text { Sense of place } \\
\text { against }\end{array}$ & 0.00 & 0.05 & $-0,272$ \\
Social anxiety & & & \\
\hline
\end{tabular}

Based on Table 5. above the results of spearman rank correlation analysis shows that the significance value is 0.00 because the significance value is smaller than 0.05, it can be concluded that $H_{o}$ is rejected and $H_{a}$ is accepted. This means that there is a significant relationship between the sense of place and social anxiety on new students of the Tarbiyah and Teaching Faculties of the State Islamic University Raden Intan Lampung.

Negative correlation coefficient shows a negative relationship between variable $(\mathrm{X})$ and variable $(\mathrm{Y})$, meaning that if the sense of place increases, social anxiety decreases, and vice versa, if the sense of place decreases, social anxiety increases. 


\section{DISCUSSION}

This study aims to determine the relationship between sense of place and social anxiety in students of the Faculty of Tarbiyah and Teaching of the State Islamic University Raden Intan Lampung. Based on the results of the correlation test it is known that the significance value is less than 0.05, which is 0.00 , which means that $H_{O}$ is rejected and $H_{a}$ is accepted, it can be interpreted that there is a relationship between the sense of place and social anxiety on students from Tarbiyah Faculty and University Teaching Islam Negeri Raden Intan Lampung.

The correlation between the sense of place and social anxiety was obtained from the correlation coefficient of -0.272 with $\mathrm{p}<0.05$. A negative sign indicates that there is a negative relationship between the independent variable and the dependent variable. This means that the increase in the score of the independent variable ( sense of place ) together will be followed by a decrease in the score of the dependent variable ( social anxiety), and vice versa, a decrease in the score on the independent variable together will be followed by an increase in the dependent variable score. Correlation coefficients of -0.272 indicate that correlations are low or small.

Based on the above description it can be concluded that the sense of place has a relationship with social anxiety, individuals who have a high sense of place tend to have low social anxiety but on the contrary, individuals who have a low sense of place tend to have high social anxiety.

Jorgenson and Stedman define the sense of place as meaning attached to a setting of space for a person or group, the sense of place is not inspired by the physical state of one's own place but in the human interpretation of the situation (Jorgensen, 2001). The environment that is closest and most tangible to humans is the physical-physio-nature, both geographical location and residential area, which will more or less affect a person's psychology ( Winata, 2012).

Migrant students who choose to live in Bandarlampung will experience situations that are different from the situation in their place of origin, differences in culture, language, communication, etc., but immigrant students cannot be separated from good interactions with the environment and with other individuals in the place. From this interaction a special meaning will be formed on the place, this meaning is called 
the sense of place. The bad meaning can be perceived as a stressor by individuals ( Arief , 2015).

Stimulus from the environment will be judged by individuals, where in this assessment will emerge a reaction and as a result if an individual can overcome the stimulus coming from the environment a condition will be created, the condition can be adaptation (tolerating the environment) or adjustment(individuals change the environment to suit it ) Conversely, if individuals fail to overcome the stimulus that comes there will be stress, anxiety, illness and so forth.

The existence of cultural differences and not yet know each other will cause a person psychologically to experience anxiety where anxiety or concern related to this social situation is called social anxiety. That differences between conditions in the area of origin and in the new area can bring things that are not pleasant for an immigrant student.

Mental health problems that may occur to foreigners or migrants who live outside their home areas, problems that cause experienced distress including loss of family and friends, language, culture, hometown, etc., besides the difficulty in expressing sadness can cause mental problems, exposure to sadness they experience causes them to define satisfaction with their current place or location.

Sense of place has a significant contribution to mental health, namely a low sense of place has a role in mental health problems, for example, a low sense of place causes anxiety, mood disorders and behavioral disorders ( Rostamzadeh, 2012).

Migrant students leave their place of origin including leaving parents, family and friends, this can cause distress or sadness. From the sadness or stress that the natural person will influence their interpretation of the current place or location.

Sense of place is give a significant contribution to mental health, namely a low sense of place has a role in mental health problems, for example, a low sense of place causes anxiety, mood disorders and behavioral disorders ( Rostamzadeh, 2012).

\section{CONCLUSION}

The conclusion of this study is that there is a relationship between the sense of place and social anxiety on students of the Tarbiyah Faculty and Teaching Faculty of the State Islamic University Raden Intan Lampung. The 
results of the hypothesis test found that there is a relationship between the sense of place and social anxiety.

Correlation coefficient of -0.292 shows that the correlation is low or small, while the negative sign indicates that there is a negative relationship between the sense of place and social anxiety, meaning that if there is a decrease in the score of the place will be followed by an increase in social anxiety or vice versa.

\section{REFERENCES}

Altman, I, Wohlwill, J. 1977. Human Behavior and Environment Volume 2. New York : Plenum Press.

Davision, G. C., Neale, J. M., \& Kring, A. M. 2012. Psikologi Abnormal. Jakarta: PT Raja Grafindo Persada.

Iskandar, Z. 2012. Psikologi Lingkungan Teori dan Konsep. Bandung: PT. Refika Aditama.

Jorgensen, B. Stedman, R. 2001. Sense of Place as an Attitude: Lakeshore Owners Attitudes Toward Their Properties. Journal of Environmental Psychology. 21, 233-248. doi:10.1006/jevp.2001.0226.

Juntilla, N, Laakonen, E, Niemi, dan Ranta, K. 2011. Modeling the Interrelations of Adolescent, Loneliness, Social Anxiety and Social Phobia. Center for Learning Research, University of Turku.

Kreifelts, B., Bruck, C., Ritter, J., Ethofer, T., Domin, M., Lotze, M., Jacob, H., Schlipf, S., dan Wildgruber, D. 2014. They Are Laughing at Me: Cerebral Mediation of Cognitive Biases in Social Anxiety. University of Leicester, United Kingdom. 9 (6).doi:10.1371/journal.pone.0099815.

Muarifah, A. 2005. Hubungan Kecemasan dan Agresivitas. Indonesian Psychological Journal. 2 (2).

Nurhayati, Y. 2015. Sense of Place pada Masyarakat yang Tinggal di Sekitar TPA Sumpiuh Kota Baru. JurnalPsikologi. 1 (03).

Prawoto, Y. 2010. Hubungan Antara Konsep Diri Dengan Kecemasan Sosial pada Remaja Kelas XI SMA Kristen 2 Surakarta. Jurnal. Program Studi Psikologi Fakultas Kedokteran Universitas Sebelas Maret Surakarta.

Rahmawati, S., Yusainy, C., Nurwanti, R. 2014. Peranan Jenis Komentar Terhadap Hubungan Antara Kecemasan Sosial dan Perilaku Agresif Pelaku Selfie. JurnalPsikologi 03 (9). 
Rostamzadeh, M, Anantharaman, R, Tong, D. 2012. Sense of Place on Expatriate Mental Health in Malaysia. Iternational Journal of Social Science and Humanity. 2 (5). Doi: 10.7763/IJSSH.2012.V2.126.

Suliyanto. 2004. Statistika Non Parametrik dalam Aplikasi Penelitian. Yogyakarta: CV.Andi Offset.

Swasti, I, Martani, W. 2013. Menurunkan Kecemasan Sosial melalui Pemaknaan Kisah Hidup. Jurnal Psikologi Universitas Gadjah Mada. $40(01)$

Villiers, D. 2008. Perfectionism and Social Anxiety among College Students. Counseling Psychology Dissertations. Disertasi.

Winata, A. 2012. Adaptasi Sosial Mahasiswa Rantau dalam Mencapai Prestasi Akademik. JurnalPsikologi. 3 (02). 